\title{
Analisis Kemampuan Berpikir Kritis Matematis Siswa Kelas VIII dalam Soal High Order Thinking Skill
}

\author{
Nisrina Hani Prasetyo*, Dani Firmansyah \\ Program Studi Pendidikan Matematika, Universitas Singaperbangsa Karawang, Indonesia \\ *Coresponding Author: 1810631050099@student.unsika.ac.id
}

Article History:

Received 2022-01-28

Revised 2022-02-24

Accepted 2022-03-05

DOI

10.31949/educatio.v8i1.1958

\begin{abstract}
This study aims to analyze students' mathematical critical thinking skills on questions that require a high level of thinking or high order thinking skills (HOTS). The subjects of this study were 22 students of class VIII in a school in West Karawang district. Descriptive qualitative is the method used in this research, accompanied by data analysis using an interactive model from Miles \& Huberman. The instrument used in the study was a HOTS-based adoption question with 3 questions using indicators of students' mathematical problem solving abilities according to Perkins \& Murphy which consisted of clarification, assessment, strategies, and interference. The results showed that students with low category abilities did not meet the four indicators of critical thinking skills at all. Students with moderate category ability can pass the three indicators of critical thinking ability well, while students with high category ability can pass all indicators of critical thinking ability properly and correctly.
\end{abstract}

Keywords: analysis; critical thinking ability; hots

\section{PENDAHULUAN}

Matematika merupakan salah satu ilmu dasar yang memegang peranan penting dalam peningkatan teknologi dan ilmu pengetahuan. Eksistensi matematika sangatlah penting sebab matematika merupakan ilmu universal yang dapat di terapkan dalam berbagai bidang ilmu pengetahuan. Menurut Amirali (Mahendra et al., 2016) menambahkan "Mathematics is at the heart of many successful careers and successful live for societal development, particularly in the extraordinary and accelerating change circumstances". Pada era 21 ini terjadi revolusi industri dimana tujuan pendidikan di era revolusi industri diharapkan dapat memperoleh lulusan pendidikan yang kompeten dalaam memanfaatkan ICT (Information and Communication Technologies) juga dalam kemampuan literasi, memecahkan masalah, berpikir kritis, komunikasi, dan memiliki kualitas karakter yang baik. 
Kemampuan berpikir kritis adalah proses dalam kognitif murid untuk menganalisa permasalahan yang ditemui, mengidentifikasi serta menelaah informasi untuk menyusun strategi dari permasalahan itu sendiri. (Alexandra \& Ratu, 2018) berpikir kritis merupakan salah satu komponen utama dalam belajar khususnya matematika yang harus dimiliki oleh siswa pada waktu pembelajaran di sekolah. Keterampilan berpikir kritis dikembangkan dengan melakukan pembiasaan pada permasalahan yang kontradiktif dan baru dengan tujuan siswa dapat mencari alasan yang logis untuk mengambil suatu keputusan ataupun kesimpulan serta menyelesaikan permasalahan khususnya pada pembelajaran matematika dengan benar dan tepat. Dengan begitu, siswa juga mampu menghasilkan kesimpulan yang benar.

Menurut As'ari (Wahyuningrum et al., 2021) Saat ini pembelajaran memiliki komunikasi yang hanya bersifat satu arah, pengaturan kelas yang terlalu monoton, low order thinking skill, bergantung pada sumber buku paket saja, lebih dominan soal rutin dan pertanyaan tingkat rendah serta lebih fokus pada kemampuan prosedural. Pada penelitian juga menjelaskan bahwa kenyataan yang terjadi di lapangan mnunjukkan bahwa guru-guru matematika kesusahan untuk meningkatkan kemampuan berpikir kritis siswa melalui pembelajaran matematika. Seorang murid dapat dikatakan mempunyai kemampuan berpikir kritis jika murid tersebut memiliki cara berpikir kritis yang sistematis, kesadaran dalam berpikir, dan memiliki keterampilan untuk membedakan suatu kebenaran dari kesalahan yang dijumpai. Sehingga faktor penyebab kemampuan berpikir kritis rendah dari sisi seorang guru adalah guru umumnya masih membagikan soal bertipe low order thinking skill dan faktor penyebab kemampuan berpikir kritis rendah dari sisi peserta didikatau murid-murid adalah tidak terbiasa murid mengerjakan soal bertipe High Order Thinking Skill (HOTS). Soal-soal matematika dalam kurikulum 2013 dipandang sebagai permasalahan yang sukar bagi siswa, perihal ini disebabkan oleh banyaknya soal pada kurikulum 2013 yang membutuhkan keterampilan berpikir tingkat tinggi.

Menurut Saputra (Raharjo et al., 2019) High Order Tbinking Skill ialah suatu proses berpikir kognitif dalam level tingkat tinggi siswa yang ditumbuhkan dari berbagai aspek dan teknik kognitif serta taksonomi pembelajaran seperti metode problem solving, taksonomi bloom, dan taksonomi pembelajaran, pengajaran, serta penilaian. Dalam Kemendikbud, soal bertipe HOTS ini merupakan soal-soal yang mengukur keterampilan dalam (1) mentransfer suatu konsep ke konsep lain; (2) memproses dan menggunakan informasi; (3) mencari keterkaitan dari beragam informasi yang berbeda; (4) menerapkan informasi untuk mengatasi permasalahan; dan (5) menelaah ide dan informasi secara kritis. Berdasarkan hal tersebut, maka peneliti akan menganalisis kemampuan berpikir kritis matematis siswa kelas VIII dalam mengerjakan soal bertipe HOTS.

Dalam hasil penelitian (Nuryanti et al., 2018) dikatakan bahwa kemampuan brpikir kritis siswa SMP kelas VIII masih rendah dikarenakan rendahnya pencapaian rata-rata kategori jawaban benar dari keseluruhan jawaban siswa yang diteliti. Begitupun dengan hasil penelitian (Septiana et al., 2019) nilai-nilai presentase dari semua indikator kemampuan berpikir kritis SMP pada materi bangun ruang sisi datar masih sangat rendah yaitu berada di bawah 50\%. Perbedaan penelitian ini dengan penelitian sebelumnya adalah peneliti ingin kembali menganalisa bagaimana kemampuan berpikir kemampuan kritis yang dibagi dengan kategori tinggi, sedang dan rendah pada soal yang berbasis tingkat tinggi khususnya pada materi pola bilangan. Tujuan dari penelitian ini adalah menganalisa secara menyeluruh kemampuan berpikir kritis siswa kelas VIII terhadap soal yang memerlukan taraf berpikir tingkat tinggi.

\section{METODE PENELITIAN}

Penelitian ini menggunakan penelitian kualitatif dengan metode deskriptif. (Sugiyono, 2015) mendefinisikan bahwa penelitian kualitatif sebagai metode penelitian yang didasarkan dengan filsafat postpositivisme yaitu nyata, ada, sesuai dengan hukum alam dengan tujuan untuk mempelajari keadaan objek alamiah dengan anggapan peneliti sebagai alat utamanya, lalu metode pengumpulan dilakukan dengan triangulasi, kemudian analisis data bersifat kualitatif, serta hasil yang disajikan berfokus pada suatu makna daripada generalisasi. Menurut (Moleong, 2012) juga menambahkan bahwa penelitian deskriptif berupa data yang diklasifikasikan ke dalam bentuk kata-kata, gambar, bukanlah angka.

Open Access: https://ejournal.unma.ac.id/index.php/educatio 
Penelitian ini dilakukan pada tanggal 10 November 2021. Subjek pada penelitian kali ini adalah 22 siswa kelas VIII di salah satu sekolah kabupaten Karawang Barat. Instrumen tes kemampuan berpikir kritis ini berupa tiga soal uraian yang diadopsi dari (Ramli, 2020) tentang materi pola bilangan. Instrumen tes ini digunakan untuk melihat bagaimana kemampuan berpikir kritis matematis siswa. Peneliti menggunakan indikator kemampuan berpikir kritis matematis siswa menurut Perkins \& Murphy juga instrumen wawancara semi terstruktur kepada beberapa siswa yang memiliki kemampuan rendah, sedang, dan tinggi.

Penelitian ini menggunakan model analisis Miles dan Huberman (Sugiyono, 2015) yang terdiri dari empat tahap analisis. Tahap awal pada penelitian ini dengan mengumpulkan data dimana peneliti akan mengakumulasikan data dari hasil jawaban tes kemampuan berpikir kritis siswa serta data hasil dari wawancara semi terstruktur kepada responden yang terpilih. Tahap kedua pada penelitian ini dengan mereduksi data dimana peneliti mengelompokkan kemudian merangkum dan menkhususkan pada point-poin penting menjadi suatu kalimat yang ringkas. Tahap ketiga pada penelitian ini dengan menyajikan data dimana peneliti mengubah data secara sistematis kemudian dituliskan ke dalam bentuk naratif dengan interpretasi yang lugas. Tahap terakhir pada penelitian ini yaitu peneliti mengambil kesimpulan atau verifikasi secara tentatif berdasarkan keseluruhan data yang telah diperoleh.

\section{HASIL DAN PEMBAHASAN}

Hasil perhitungan nilai dari dua puluh dua siswa tersebut didapatkan untuk nilai maksimal sebesar 90, nilai terkecil sebesar 15 dan nilai rata-rata siswa sebesar 36,14 serta nilai standar deviasi atau simpangan baku sebesar 20,93. Selanjutnya kedua puluh dua siswa tersebut dikelompokkan sesuai dengan kemampuan yang dimiliki pada tabel kategori pengelompokkan siswa.

Tabel 1. Kategori Pengelompokkan Kemampuan Siswa

\begin{tabular}{lccc}
\hline Kriteria & Kategori & Jumlah Siswa & Persentase \\
\hline Nilai $>57,06$ & Tinggi & 4 & $18,2 \%$ \\
$57,06<$ Nilai $<15,21$ & Sedang & 15 & $68,2 \%$ \\
Nilai $<15,21$ & Rendah & 3 & $13,6 \%$ \\
\hline
\end{tabular}

Berdasarkan tabel 1, siswa yang memiliki kemampuan rendah sebanyak 3 orang atau 13,6 persen dari keseluruhan responden dengan rentan nilai kurang dari 15,21. Siswa yang memiliki kemampuan sedang sebanyak 15 orang atau 68,2 persen dari keseluruhan responden dengan nilai berada diantara 57,06 - 15,21. Sedangkan siswa yang memiliki kemampuan tinggi ada sebanyak 4 orang atau 18,2 persen dari total reponden dengan rentan nilai lebih dari 57,06.

Selanjutnya akan dijabarkan analisis hasil jawaban siswa dari setiap perwakilan kelompok siswa yang memiliki kemampuan berpikir kritis kategori rendah, kategori sedang dan kategori tinggi.

Analisis Hasil Jawaban Siswa Berkemampuan Rendah

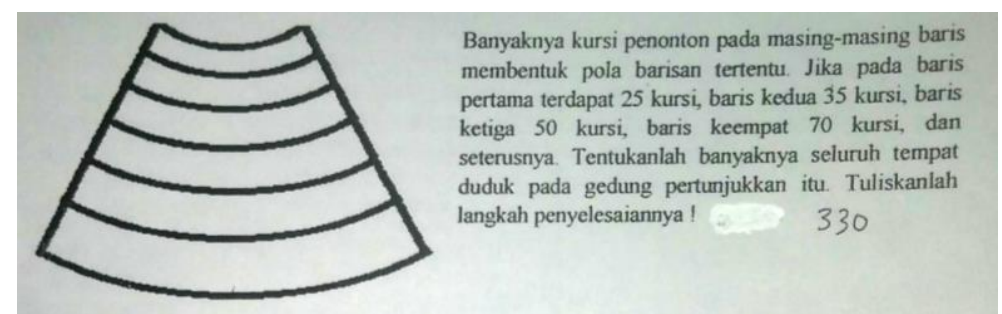

Gambar 1. Hasil jawaban siswa berkemampuan rendah nomer 1

Pada soal nomer 1 siswa hanya menuliskan jawabannya saja secara langsung tanpa menuliskan langkah-langkah yang di haruskan sehingga siswa telah melewatkan hampir semua indikator pada kemampuan berpikir kritis baik pada tahap indikator clarification, indikator assessment, indikator inference, maupun indikator strategies. Dalam wawancara sekalipun siswa mengaku tidak mengerti maksud dari permasalahan soal yang 
diberikan sehingga siswa tidak bisa membuat rencana penyelesaian dengan benar. Kasus ini sama seperti penelitian (Hidayat et al., 2019) bahwa mereka tidak terlatih untuk membuat suatu pemodelan matematika dan tidak dapat menentukan metode apa yang sesuai untuk menyelesaikan soal tersebut. Mereka hanya terbiasa membuat keterangannya saja dan langsung menjawab soal tanpa memerhatikan metode yang digunakan.

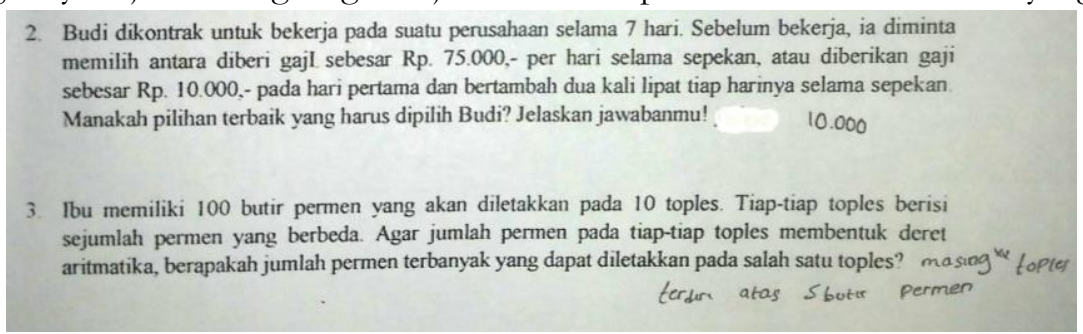

Gambar 2. Hasil jawaban siswa berkemampuan rendah nomer 2 dan 3

Pada soal nomor 2 dan nomor 3 pun siswa dengan kemampuan rendah hanya menulis jawaban spontan saja tanpa diikuti dengan bukti-bukti penyelesaian yang dilakukan. Pada wawancara, siswa berkemampuan rendah mengatakan tidak mengerti dengan maksud soal yang diberikan sehingga siswa telah gugur pada indikator klarifikasi dimana siswa dapat menyatakan, mengklarifikasi, menggambarkan atau mendefinisikan masalah yang dituangkan pada soal. Jawaban yang diberikan oleh siswa berkemampuan rendah ini seharusnya bisa menjadi jawaban yang benar karena siswa tersebut menyebutkan salah satu pilihan yang disediakan pada soal, tetapi karena siswa tidak mampu mnjelaskan alasan dari jawaban yang diberikan maka jawaban tetap dinyatakan salah. Siswa mengaku jawaban yang diberikan hanya berupa perkiraan saja tanpa diikuti alasan yang kuat pada jawaban yang telah ditulis/dipilih. Hal ini juga berkaitan dengan penelitian (Purwati et al., 2016) bahwa siswa dengan kemampuan berikir kritis rendah tidak mampu menganalisis, mengevaluasi serta menginferensi.

Analisis Hasil Jawaban Siswa Berkemampuan Sedang

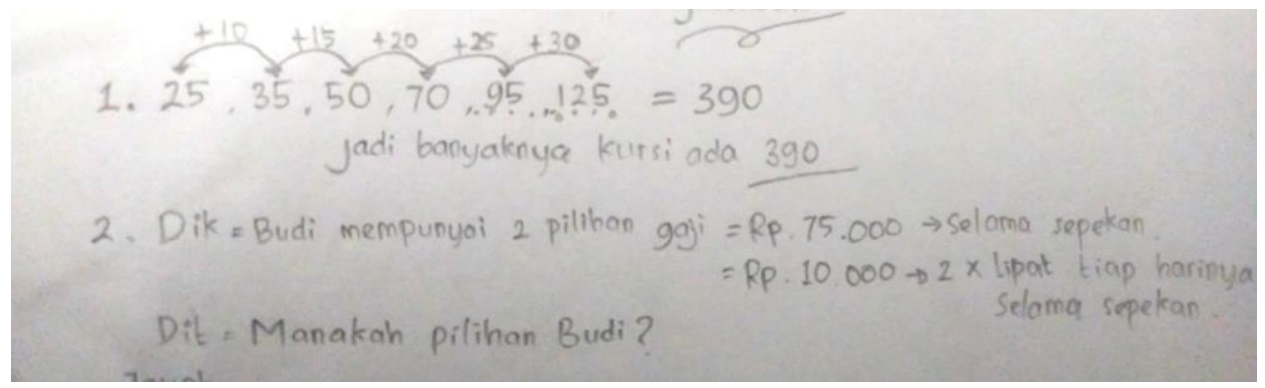

Gambar 3. Hasil jawaban siswa berkemampuan sedang nomer 1 dan 2

Pada soal nomor 1 siswa telah menyatakan dan mendefinisikan masalah pada soal yang diberikan. Hal ini terbukti dengan cara siswa melengkapi pola yang diberikan dalam soal sesuai dengan masalah pada soal tersebut. Pada indikator asesmen siswa dengan kemampuan sedang dapat mengungkapkan ide atau konsep yang akan digunakan yaitu konsep deret aritmatika. Selanjutnya pada indikator strategies, siswa keliru dalam menjumlahkan hasil keseluruhan yang didapatkan walaupun konsep yang digunakan sudah benar. Kesimpulan yang diberikan oleh siswa dengan kemampuan sedang pun salah karena tidak dapat mengoperasikan dengan baik hasil yang telah diperoleh sehingga siswa tersebut tidak memperoleh jawaban yang tepat. Sama seperti penelitian (Zaki et al., 2021) dimana siswa yang berada pada kategori rendah kebanyakan tidak membuat kesimpulan dengan tepat karena hanya melakukan perhitungan saja.

Pada soal nomor 2 siswa hanya menuliskan hal-hal yang telah diketahui dan yang ditanyakan pada soal tersebut sehingga ini membuktikan bahwa siswa dengan kemampuan sedang telah memahami soal dengan baik yaitu pada indikator clarification. Sebaliknya, pada hasil penelitian (Fitriatien, 2019) ada subjek penelitian tidak menuliskan yang diketahui, sehingga makna soal tidak berarti yang sesungguhnya. Selanjutnya 
siswa tidak meneruskan indikator lainnya sehingga siswa tersebut hanya mampu melalui tahap indikator klasifikasi.

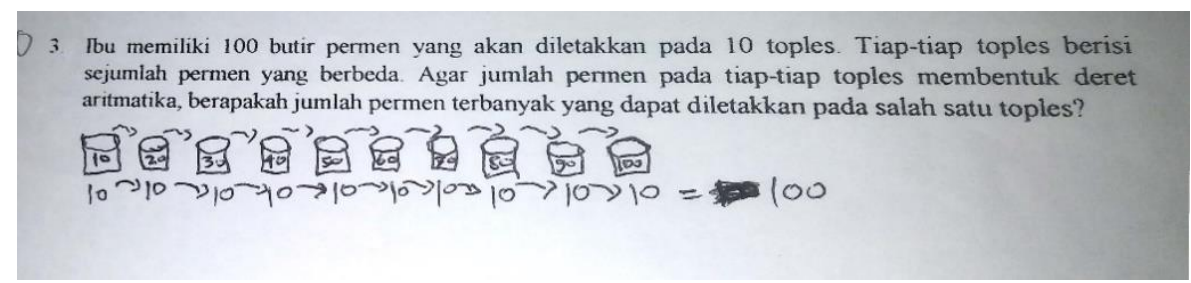

Gambar 4. Hasil jawaban siswa berkemampuan sedang nomer 3

Pada soal nomor 3 siswa tersebut melakukan perencanaan dalam menyelesaikan masalah dengan menggambarkan bentuk toples sebanyak yang diperintahkan lalu siswa mulai mencoba memikirkan cara bagaimana tiap-tiap permen dapat mengisi semua toplesyang telah disediakan. Siswa menggambarkan penyelesaian masalah dengan cara mengisi setiap toples sama banyak. Hal ini membuktikan bahwa siswa telah melaksanakan indikator clarification dan assessment tetapi karena siswa melupakan fakta tentang urutan pengisian permen mengikuti barisan aritmatika maka rencana dan hasil yang diperoleh salah. Kasus seperti ini sama seperti penelitian oleh (Danaryanti \& Lestari, 2018) dimana masih banyak siswa yang memaksakan agar sebuah kesimpulan selalu benar, tanpa memerhatikan apakah informasi yang didapatkan valid atau tidak. Karena siswa tersebut mengisi setiap toples dengan jumlah permen yang sama banyak, maka urutan pengisian permen pada setiap toples tersebut tidak mengikuti aturan barisan aritmatika. Alhasil siswa berkemampuan sedang tidak dapat memperoleh jawaban dengan tepat.

\section{Analisis Hasil Jawaban Siswa Berkemampuan Tinggi}

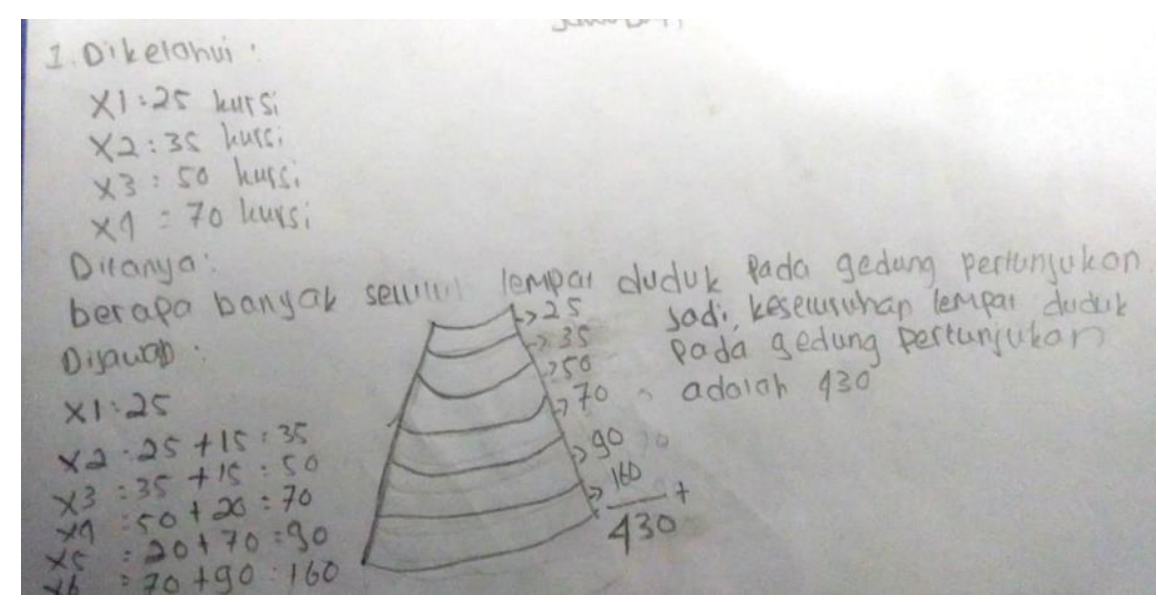

Gambar 5. Hasil jawaban siswa berkemampuan tinggi nomer 1

Pada soal nomor 1 siswa dengan kemampuan tinggi menuliskan hal-hal yang diketahui dan ditanyakan sesuai dengan penyajian dalam soal tersebut sehingga siswa telah memenuhi indikator clarification. Setelah itu siswa telah membuat rencana dengan merincikan setiap suku pada barisan kursi yang tersedia yaitu dengan mencari hasil penjumlahannya. Tetapi cara yang dilakukan oleh siswa tersebut tidak sesuai dengan urutan barisan yang diinginkan sehingga siswa keliru dalam membuat ide atau konsep penyelesaikan begitu pun dengan hasil rencana yang telah dihitung. Siswa masih menerapkan prosedur matematika yang keliru dalam menyelesaikan masalah dikarenakan pengetahuan yang terbatas tentang prinsip, aturan, dan prosedur matematika (Nurapipah \& Zulkarnaen, 2019). Sehingga dapat disimpulkan bahwa siswa belum memenuhi tahap strategies. 


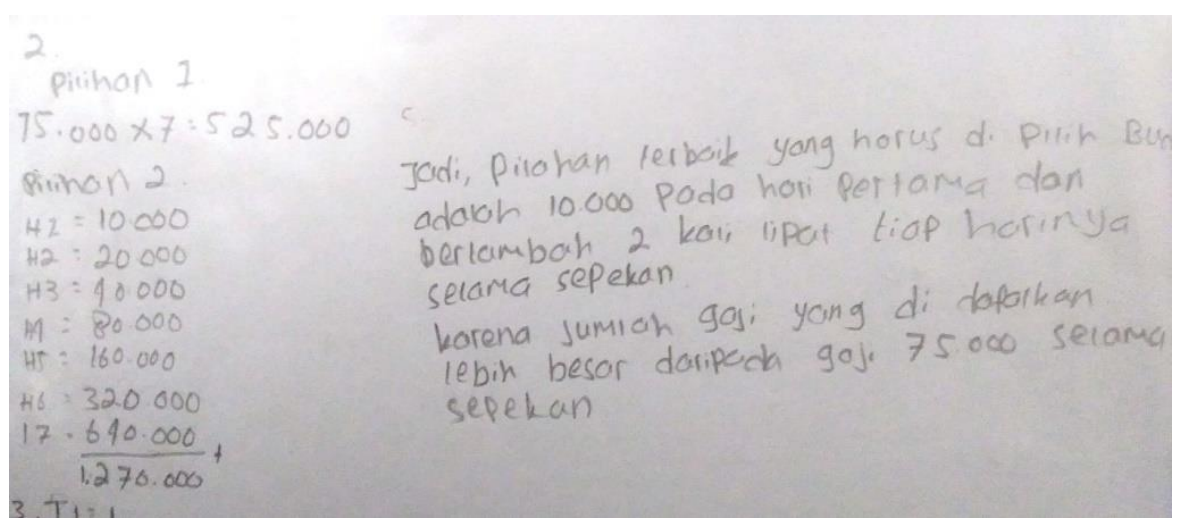

Gambar 6. Hasil jawaban siswa berkemampuan tinggi nomer 2

Pada soal nomor 2 siswa dengan kemampuan tinggi menjabarkan konsep yang akan disiapkan yaitu menuliskan hasil dari setiap pilihan yang tersedia setelah itu siswa memilih hasil yang lebih banyak sebagai jawaban yang tepat. Saat wawancara, siswa pun mampu menerangkan alasan dari jawaban yang telah ditulis. Sama halnya dengan penelitian (Farib et al., 2019) dimana siswa memilih berbagai penyelesaian masalah dan mencoba untuk menyelesaikannya untuk mendapatkan kesimpulan yang tepat dari penyelesaian masalah. Dalam kasus ini siswa telah berhasil melalui indikator clarification, dan assessment. Perhitungan yang dilakukan oleh siswa pun benar sesuai dengan konsep yang dibuat. Sehingga siswa telah berhasil melakukan indikator strategies. Pada indikator interference pun siswa telah berhasil mengemukakan kesimpulan dari hasil jawaban yang diperoleh.

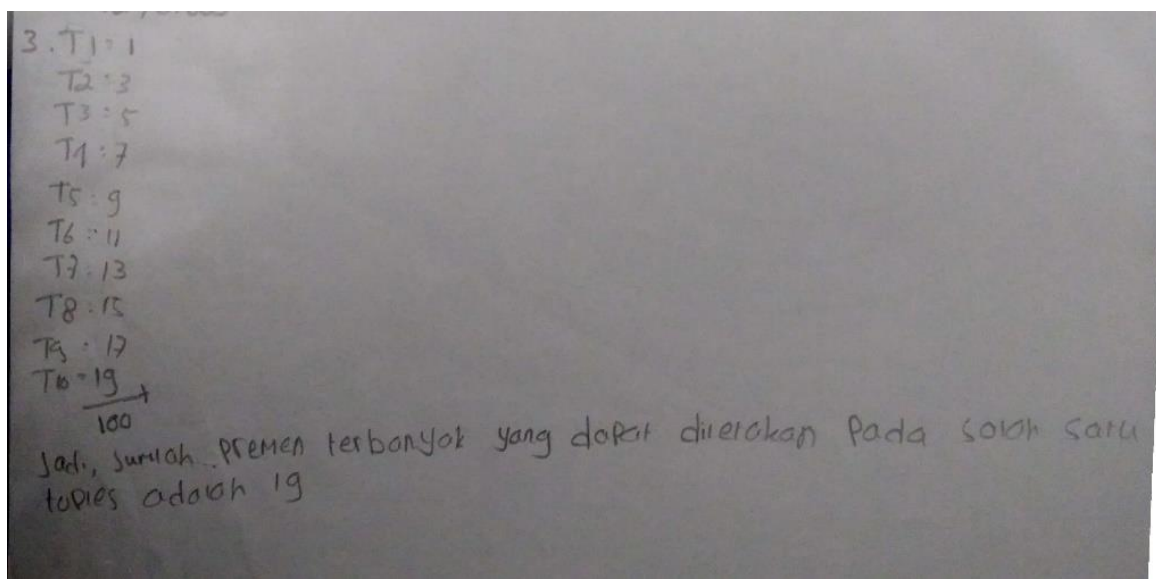

Gambar 7. Hasil jawaban siswa berkemampuan tinggi nomer 3

Pada soal ketiga, siswa dengan kemampuan tinggi mencoba membuat pola bilangan yang sesuai dengan pola bilangan yang dimaksud pada soal. Berdasarkan hasil wawancara kepada siswa tersebut, diperoleh bahwa sebelumnya siswa telah menuliskan pola dengan angka yang berbeda tetapi tetap pada aturan deret aritmatika. Siswa terus menuliskan satu persatu kemungkinan sampai siswa menemukan pola bilangan yang sessuai dengan masalah yang diberikan. Siswa mengaku sangat sulit membuat banyaknya kemungkinan untuk memperoleh hasil yang sesuai dengan permasalahan yang diberikan. Alhasil siswa tersbut tetap tidak menyerah mencoba satu per satu kemungkinan. Dengan demikian siswa tersebut telah berhasil melalui indikator assessment dan indikator strategies. Sama halnya dengan penelitian (Azizah et al., 2018) bahwa siswa kategori sangat tinggi sudah mampu memahami permasalahan yang disajikan, menulis fakta dan mengajukan pertanyaan dengan tepat, merencanakan strategi penyelesaian masalah, dan mengevaluasi keputusan dengan benar. Kesimpulan yang diambil oleh siswa berkemampuan tinggi ini juga merupakan kesimpulan yang tepat terkait soal yang disajikan karena siswa berhasil menemukan urutan yang tepat setelah mencoba beberapa kali kemungkinan.

Berdasarkan hasil deskripsi pada lembar jawaban dan wawancara dari ketiga siswa tersebut, dapat diperoleh analisis tahapan kemampuan berpikir kritis berdasarkan indikator Perkins \& Murphy sebagai berikut

a. Klarifikasi (Clarification) 
Dari hasil penelitian pada indikator clarification atau klasifikasi didapatkan bahwa siswa berkemampuan rendah tidak dapat melalui indikator tersebut. Hal ini dibuktikan dengan wawancara pada beberapa siswa yang mengatakan bahwa siswa tidak mengerti maksud dari soal yang diberikan sehingga tidak bisa menyatakan ataupun mendefinisikan masalah yang diberikan. Selanjutnya siswa dengan kemampuan sedang dan tinggi sudah dapat melalui tahap klasifikasi dengan menuliskan ataupun menjelaskan masalah yang diberikan melalui wawancara. Hal ini terlihat dari ccara mereka menuliskan hal-hal yang diketahui ataupun ditanyakan serta berhasil menjelaskan masalah apa yang terkandung dalam soal. Klarifikasi dalam penelitian (Nashrullah et al., 2021) merupakan tahap dimana siswa menyatakan atau mendefinisikan suatu masalah dengan menuliskan informasi yang diketahui secara tepat. Sehingga hanya siswa dengan kemampuan sedang dan tinggi saja yang dapat melewati indikator klarifikasi dengan tepat dan benar.

b. Asesmen (Assessment)

Pada indikator assessment diperoleh bahwa siswa berkemampuan rendah belum dapat membuat konsep ataupun ide yang digunakan dalam menyelesaikan soal berbasis HOTS ini. Dikarenakan siswa berkemampuan rendah hanya menjawab soal secara spontan tanpa menjabarkan asesmen ataupun rencana penyelesaian yang dimiliki. Sedangkan siswa dengan kemampuan sedang dan tinggi sudah dapat merencanakan konsep yang dilakukan untuk menyelesaikan soal walaupun pada siswa berkemampuan sedang, masih keliru dalam membuat konsep penyelesaian karena kurangnya pemahaman materi khususnya pada materi pola bilangan. Siswa dengan kemampuan tinggi sudah dapat melewati indikator ini secara benar dan tepat karena telah berhasil menjabarkan dan menjelaskan jawaban yang telah diperoleh. Tahap asesmen ini dalam penelitian (Rachmantika \& Wardono, 2019) dijelaskan sebagai tahap dalam mengemukakan fakta-fakta argumen ataupun menghubungkan masalah dengan masalah yang lain.

c. Strategi (Strategies)

Berdasarkan hasil penelitian, pada indikator strategies siswa dengan kemampuan rendah belum dapat melakukan strategi yang digunakan karena siswa berkemampuan rendah sedari awal tidak memahami maksud dari soal HOTS yang diberikan. Seperti yang sudah dijelaskan sebelumnya bahwa siswa brkemampuan rendah tidak bisa menyelesaikan soal dengan benar satu pun. Siswa dengan kemampuan sedang tidak bisa menjelaskan strategi dengan baik karena siswa dengan kemampuan sedang masih keliru dalam membuat ide ataupun konsep untuk menyelesaikan soal tersebut. Siswa berkemampuan tinggi sudah dapat menjelaskan strategi yang digunakan dengan baik walaupun terkadang mereka keliru dengan konsep yang digunakan berbeda dengan hasil yang diperoleh. Dalam hal tersebut proses berpikir kritis menuntut penggunaan strategi yang cukup untuk mendapatkan suatu keputusan sebagai dasar pengambilan keyakinan atau tindakan, sehingga tindakan yang diambil cukup dan relevan (Andini \& Warni, 2019) .

d. Penyimpulan (Interference)

Dengan melihat hasil survei dan wawancara dari beberapa siswa diperoleh bahwa siswa berkemampuan rendah tetap belum bisa menjelaskan kesimpulan apa yang diambil dari hasil yang telah dituangkan. Sedangkan siswa berkemampuan sedang dan tinggi sudah dapat menyimpulkan mengenai gambaran apa yang telah dihasilkan oleh masing-masing jawaban. Dalam wawancara pun, siswa berkemampuan sedang dan tinggi dapat menjelaskan dengan benar permasalahan apa yang diberikan serta penyelesaian apa yang telah mereka berikan pada setiap masing masing lembar jawaban. Tahap penyimpulan dalam (Rachmantika \& Wardono, 2019) ditandai dengan siswa dapat menggeneralisasi, menjelaskan dan membuat hipotesis serta menggambarkan kesimpulan yang tepat dengan induksi dan reduksi. 


\section{KESIMPULAN}

Berdasarkan hasil analisis yang diperoleh dari dua puluh dua siswa dalam mengerjakan soal matematik bertipe HOTS didapatkan bahwa, kemampuan berpikir kritis pada siswa yang memiliki kemampuan tinggi dapat memenuhi seluruh indikator baik dalam klarifikasi, asesmen, strategi dan penyimpulan. Siswa berkemampuan sedang dapat memenuhi tiga dari empat indikator kemampuan berpikir kritis yaitu pada indikator klarifikasi, asesmen, dan penyimpulan. Hanya saja siswa masih keliru dalam membuat asesmen akibatnya tidak bisa memenuhi indikator stategi dalam kemampuan berpikir kritis. Sedangkan siswa dengan kemampuan rendah sama sekali belum bisa memenuhi keempat indikator tersebut. Penyebab siswa tidak dapat melewati indikator kemampan berpikir kritis adalah karena mereka tidak terbiasa dengan soal cerita berbasis HOTS dan selalu terbiasa dengan soal tingkat rendah.

\section{DAFTAR PUSTAKA}

Alexandra, G., \& Ratu, N. (2018). Profil Kemampuan Berpikir Kritis Matematis Siswa SMP Dengan Graded Response Models. Mosharafa: Jurnal Pendidikan Matematika, 7(1), 103-112.

Andini, V., \& Warni, A. (2019). Analisis Tingkat Kemampuan Berpikir Kritis Matematis Siswa SMP Kelas VIII Pada Materi Relasi dan Fungsi. Prosiding Seminar Nasional Matematika Dan Pendidikan Matematika Sesiomadika 2019, 594-601. https://journal.unsika.ac.id/index.php/sesiomadika/article/view/2654

Azizah, M., Sulianto, J., \& Cintang, N. (2018). Analisis Keterampilan Berpikir Kritis Siswa Sekolah Dasar pada Pembelajaran Matematika Kurikulum 2013. Jurnal Penelitian Pendidikan, 35(1), 61-70. https://doi.org/10.15294/jpp.v35i1.13529

Danaryanti, A., \& Lestari, A. T. (2018). Analisis Kemampuan Berpikir Kritis Dalam Matematika Mengacu Pada Watson-Glaser Critical Thinking Appraisal Pada Siswa Kelas VIII SMP Negeri Di Banjarmasin Tengah Tahun Pelajaran 2016/2017. EDU-MAT: Jurnal Pendidikan Matematika, 5(2), 116-126. https://doi.org/10.20527/edumat.v5i2.4631

Farib, P. M., Ikhsan, M., \& Subianto, M. (2019). Proses berpikir kritis matematis siswa sekolah menengah pertama melalui discovery learning. Jurnal Riset Pendidikan Matematika, 6(1), 99-117. https://doi.org/10.21831/jrpm.v6i1.21396

Fitriatien, S. R. (2019). Analisis Kesalahan Siswa Dalam Menyelesaikan Soal Cerita Matematika Berdasarkan Prosedur Newman. Jurnal Ilmiah Pendidikan Matematika, 1(2), 1-12. https://doi.org/10.36706/jls.v1i2.9707

Hidayat, F., Akbar, P., \& Bernard, M. (2019). Analisis Kemampuan Berfikir Kritis Matematik Serta Kemandiriaan Belajar Siswa Smp Terhadap Materi Spldv. Joumal on Education, 1(2), 515-523. https://jonedu.org/index.php/joe/article/view/106

Mahendra, R., Murfi'ah, W., \& Adamura, F. (2016). Profil Penalaran Siswa Dalam Menyelesaikan Masalah Persamaan Kuadrat Ditinjau Dari Kemampuan Awal. Prosiding Seminar Matematika Dan Pendidikan Matematika. Solo: Universitas Sebelas Maret, November, 487-501.

Moleong, L. J. (2012). Metodologi Penelitian Kualitatif (Revisi). PT. Remaja Rosdakarya.

Nashrullah, F. R., Asikin, M., Waluya, B., \& Zaenur. (2021). Kemampuan Berpikir Kritis Matematis Siswa pada Pembelajaran Realistic Mathematics Education (RME). 12(1).

Nurapipah, S., \& Zulkarnaen, R. (2019). Studi Kasus Kemampuan Berpikir Kritis Matematis Siswa Dalam $\begin{array}{lllll}\text { Menyelesaikan Soal Trigonometri. Prosiding } & \text { T48. }\end{array}$ https://journal.unsika.ac.id/index.php/sesiomadika/article/view/2727

Nuryanti, L., Zubaidah, S., \& Diantoro, M. (2018). Analisis Kemampuan Berpikir Kritis Siswa SMP. Jurnal Pendidikan, 3(2), 155-158.

Purwati, R., Hobri, \& Fatahillah, A. (2016). Analisis Kemampuan Berpikir Kritis Siswa Dalam Menyelesaikan Masalah Persamaan Kuadrat pada Pembelajaran Model Creative Problem Solving. KadikmA, 7, 84-93. https://doi.org/10.19016/jcshokuriku.3.0_1 
Rachmantika, A. R., \& Wardono. (2019). Peran Kemampuan Berpikir Kritis Siswa Pada Pembelajaran Matematika Dengan Pemecahan Masalah. Prosiding Seminar Nasional Matematika, 2(1), 441.

Raharjo, S., Hasanah, N. F., Ramadani, N. A., \& Alkikipa, F. (2019). Hubungan Kecerdasan Emosional Terhadap Kemampuan Pemecahan Masalah Soal HOTS. Prosiding Seminar Nasional Pendidikan Universitas Subang (SENDINUSA), 1(1), 153-159.

Ramli, R. W. (2020). Analisis Kemampuan Siswa dalam Menyelesaikan Soal Matematika Tipe Higher Order Thinking Skill (HOTS) Pokok Bahasan Pola Bilangan pada Kelas VIII A SMP Negeri 1 Sungguminasa. Universitas Muhammadiyah Makassar.

Septiana, R., Febriarini, Y. S., \& Zanthy, L. S. (2019). Analisis Kemampuan Berpikir Kritis Matematis Siswa SMP. JPMI (Jurnal Pembelajaran Matematika Inovatif), 2(6), 393-400. https://doi.org/10.30862/jhm.v2i2.68

Sugiyono. (2015). Metode Penelitian Kualitatif Dan Re D. Alfabeta.

Wahyuningrum, S., Abidin, Z., \& Hasana, S. N. (2021). Analisis Kmampuan Pemecahan Masalah Matematis Siswa Dalam Mnyelesaikan Soal HOTS pada Materi SPLDV Kelas VIII SMPN Negeri 1 Kasembon. JP3, 16(1), 60-66.

Zaki, M., Rifat, M., \& Halini. (2021). Deskripsi Kemampuan Penalaran Matematis Siswa dalam Menyelesikan Soal Materi Pola Bilangan Kelas VIII SMP Negeri 4 Sungai Raya. Jurnal Pendidikan Dan Pembelajaran Khatulistiwa, 10(7). 